\author{
Maria Łuszczyńska \\ Uniwersytet Papieski Jana Pawła II w Krakowie
}

\title{
RODZINA DZIECKA OBJĘTEGO DOMOWĄ OPIEKĄ HOSPICYJNĄ. RECENZJA KSIĄŻKI
}

Grzegorz Godawa, Funkcjonowanie rodziny dziecka objętego domowa opieka hospicyjna. Studium tanatopedagogiczne, Wydawnictwo Edukacyjne AKAPIT: Toruń 2016, 448 stron, ISBN 978-83-63955-45-8.

Choroba i śmierć to tematy, które przysparzają niemałego trudu każdemu człowiekowi, poszukującemu w nich głębszego sensu. Szczególną sytuację wywołującą takie refleksje jest choroba i śmierć dziecka. Na całym świecie nieustannie analizowane są metody wspierania nieuleczalnie chorych dzieci i ich rodzin za pomocą procedur i środków medycznych, ale także zapewniających wsparcie psychiczne. Z racji tego, że sytuacja umierania dziecka jest jedną z sytuacji granicznych, pożądane jest również wsparcie duchowe.

W tak szerokim katalogu zagadnień mieści się opublikowana w 2016 roku książka ks. Grzegorza Godawy opisująca sytuację rodziny i dziecka nieuleczalnie chorego. Założeniem autora jest poddanie analizie systemu opieki i wychowania, ale zdaje się, że jest to tylko pretekst do niezwykle ciekawych analiz szerszego kontekstu psychospołecznego sytuacji dziecka nieuleczalnie chorego w rodzinie.

Omawiana publikacja składa się z jedenastu rozdziałów, podzielonych na dwie główne części - teoretyczną i empiryczną. W pierwszej z nich autor zapoznaje czytelnika ze specyfiką sytuacji choroby i śmierci dziecka, ukazując je poprzez system rodzinny, specyfikę opieki i wychowania wobec dziecka przewlekle śmiertelnie chorego, a także w kontekście instytucji, z pomocy których rodzina może korzystać, zarówno tych medycznych jak i paliatywno-hospicyjnych. W tych rozważaniach autorowi pomaga instrumentarium pedagogiki, szczególnie odtwarzanej tu tanatopedagogiki z jej podstawowymi kategoriami (głównie śmiercią, cierpieniem, zagrożeniem życia). Ponadto autor odwołuje się do dorobku psychologii, pedagogiki i etyki. 
Druga, empiryczna część rozprawy obejmuje swoim zakresem opis założeń metodologicznych badań własnych oraz sproblematyzowane omówienie ich wyników. Autor pozostaje w kręgu jakościowych badań społecznych, odwołując się do konstruktywistycznego wariantu teorii ugruntowanej, która w Polsce staje się coraz bardziej popularnym paradygmatem badawczym. Prezentując wyniki badań własnych, ukazuje perspektywę członków rodziny, w której znajduje się dziecko nieuleczalnie chore. Badania autora są osadzone w rzeczywistości hospicjum dla dzieci - instytucji działającej w wybitnie trudnym obszarze wsparcia.

Publikację wieńczy zakończenie, streszczenie poszczególnych rozdziałów, a także zestawienie tabel i wykresów. To, co stanowi niewątpliwą wartość publikacji, to bardzo obszerne zestawienie bibliograficzne, które może stać się inspiracją dla wszystkich czytelników, poszukujących możliwości poszerzenia wątków zawartych w książce ks. Grzegorza Godawy.

Wartość publikacji wynika z kilku kwestii. Po pierwsze jest to studium interdyscyplinarne, które rozważa zagadnienie umierania i śmierci z perspektywy pedagogicznej, psychologicznej, etycznej, medycznej i społecznej, ukazującej zarówno kontekst badawczy, jak i sytuacje rodzin jako instytucji świadczących pomoc dziecku śmiertelnie choremu. Stąd wnioski przedstawiane przez autora mają charakter uniwersalny. Po drugie opisywane zagadnienia są osadzone w perspektywie systemowej, uwzgledniającej zarówno potrzeby dziecka i jego rodzeństwa, jak też dorosłych - rodziców, dziadków i pośrednio pracowników instytucji pomocowych. Jest to wymagająca perspektywa opisu zjawisk społecznych, gdyż należy uwzględniać wiele różnorodnych zmiennych, a przede wszystkim jest to podejście nieocenne, co dodatkowo stawia przed badaczem wymóg bezstronności. Należy podkreślić, że autor podejmuje udaną próbę przedstawienia typologii systemów rodzinnych zmagających się z nieuleczalną chorobą dziecka. I tak na podstawie badań własnych przybliża charakterystykę rodziny ukierunkowanej tanatycznie, prezentystycznej oraz perspektywicznej. Należy wyrazić nadzieję, że ta klasyfikacja zostanie poddana szerszej dyskusji oraz znajdzie trwałe miejsce w kanonie tanatopedagogiki.

Kolejnym niewątpliwym walorem omawianego opracowania jest dobór metody badawczej, która z jednej strony jest najwłaściwsza dla tak drażliwych tematów (zastosowane podejście jakościowe), analizowanych w szerokim zakresie. $Z$ drugiej strony sama metoda jest pionierska w polskiej rzeczywistości badań społecznych, w tym pedagogicznych. Są podejmowane coraz szersze studia nad jej zastosowaniem w badaniach społecznych, ale jej bazowe założenie o braku jakichkolwiek przedzałożeń oraz hipotez zdaje się osadzać ją w istocie tego, czym są badania społeczne i w największym stopniu dowiadywać się o tym, jaka jest badana rzeczywistość. Należy zatem docenić badawczą odwagę autora i stwierdzić, że udało mu się uwypuklić we wnioskach te wątki, które są najbardziej inspirujące do dalszych poszukiwań i głębszych prób rozumienia.

Inną bardzo ważną kwestią, której autor poświęca relatywnie dużo miejsca w swoich wywodach, są zagadnienia aksjologiczne. Odnoszą się one zarówno do wątków związanych z sytuacją rodziny, prowadzeniem badań nad rodziną z dzieckiem nieuleczalnie chorym, ale też do sposobu realizowania opieki hospicyjnej. Tak złożone akcentowanie zagadnień aksjologicznych wskazuje na dużą troskę autora o swoich respondentów, 
jakość wyników badań, ale też o samą dyscyplinę, w obrębie której autor osadza swoje rozważania.

Po lekturze recenzowanej książki czytelnik odczuwa pewien niedosyt. Wypływa on z pragnienia dopytania, przedyskutowania, dokładnego przeanalizowania tych wszystkich akcentów naukowych, które się pojawiają, szczególnie w efekcie prowadzonych procedur badawczych. Świadczy to niewątpliwie o dojrzałości naukowej autora z jednej strony, jak również o prawidłowo prowadzonych badaniach, których wyniki potwierdziły prawdę o kontynuacji podjętych dociekań. Lektura tekstu niewątpliwie skłania do refleksji. Złudne jest przekonanie, że skoro w rodzinie czytelnika nie występuje zjawisko przewlekłej choroby dziecka, to sytuacja go nie dotyczy, gdyż rozważania o rodzinie i śmierci mają charakter niezwykle uniwersalny, poruszając tematy na wskroś humanistyczne.

Wspominana książka może być dobrą inspiracją dla wszystkich osób zainteresowanych kwestiami tanatologicznymi, pedagogów, rodziców, pracowników instytucji wspierających osoby przewlekle śmiertelnie chore, szczególnie dzieci. Ze względu na uniwersalną tematykę może ona zainteresować wszystkie osoby, które na co dzień mierzą się z trudem świadomości własnej śmiertelności i poszukują usensowienia tego faktu.

Publikacja jak najbardziej zasługuje na rekomendację - jako źródło inspiracji badawczych, praktycznych i wdrożeniowych. 